\section{ABSTRACT}

\title{
Performance Variation with SDC Buffer Layer Thickness
}

\author{
Ryan J. Milcarek ${ }^{\mathrm{a},}{ }^{*}$, Kang Wang ${ }^{\mathrm{a}}$, Ryan L. Falkenstein-Smith ${ }^{\mathrm{a}}$, Jeongmin Ahn ${ }^{\mathrm{a}}$
}

a. Department of Mechanical and Aerospace Engineering, Syracuse University, 255 Link Hall, Syracuse, NY 13244-1240, USA

The performance of anode-supported solid oxide fuel cells was investigated as the SDC buffer layer thickness was varied between $\sim 0.4 \mu \mathrm{m}$ and $\sim 2.3 \mu \mathrm{m}$. The thickness of the buffer layer has a significant effect with the peak performance varying in magnitude by a factor of almost three. A peak power density of $1106 \mathrm{~mW} . \mathrm{cm}^{-2}$ was achieved at $800{ }^{\circ} \mathrm{C}$ and an optimal SDC buffer layer thickness of $\sim 1.5 \mu \mathrm{m}$. The performance variation was complex due to a balance between ohmic and polarization losses, triple phase boundary area, pin holes and interfacial reactions between the BSCF + SDC cathode, SDC buffer layer, and YSZ electrolyte. Understanding this variation is essential in order to compare two fuel cells having a different porous buffer layer thickness.

Keywords: Intermediate temperature solid oxide fuel cell; Buffer layer; Interlayer; Anode supported solid oxide fuel cell

*Corresponding author. Tel.: 315443 9309; Fax: +1 3154439099.

E-mail address: rjmilcar@syr.edu (R. Milcarek). 


\section{$1 \quad$ 1. INTRODUCTION}

2 Solid oxide fuel cells (SOFCs) are promising electrochemical energy conversion devices that

3 boast high efficiency and fuel flexibility [1-3]. SOFCs often use a ytrria-stabilized zirconia

4 (YSZ) electrolyte due to its mechanical strength and performance at high temperatures

$5 \quad\left(\sim 1000^{\circ} \mathrm{C}\right)$. Despite the advantages while operating at high temperatures, there are additional

6 challenges including reduced lifetime, increased maintenance, material degradation and seal

7 failures [4,5]. Recent efforts have focused on reducing the operating temperature to

8 intermediate temperatures from $600-800^{\circ} \mathrm{C}$. Two different techniques have been used

9 extensively to improve the performance at intermediate temperatures; 1 ) reduce the electrolyte

10 thickness and/or 2) use perovskite cathode materials with higher ionic and electronic

11 conductivity at intermediate temperatures. The use of the anode-supported SOFC (AS-SOFC)

12 architecture has allowed for thin film YSZ electrolytes with enhanced performance due to a

13 reduction in the ohmic losses of the fuel cell [6-10]. Further reductions in the fuel cell

14 resistance are possible with perovskite materials like $\mathrm{Ba}_{0.5} \mathrm{Sr}_{0.5} \mathrm{Co}_{0.8} \mathrm{Fe}_{0.2} \mathrm{O}_{3-\delta}$ (BSCF) [11,12].

15 This cathode material is known for higher oxygen permeability and electro-catalytic activity compared to the Sr-doped $\mathrm{LaMnO}_{3}$ (LSM) cathode used with YSZ electrolytes, especially at

17 intermediate temperatures $[13,14]$.

Despite the potential for enhanced performance by reducing the electrolyte thickness and using a BSCF cathode, poorly conductive layers of $\mathrm{BaZrO}_{3}$ and $\mathrm{SrZrO}_{3}$ form in between BSCF and YSZ at the temperatures required for fabrication [4,15-18]. For example, $\mathrm{BaZrO}_{3}$ is 
1 after sintering BSCF on YSZ substrates at $1000^{\circ} \mathrm{C}$ [4], but has also been detected after

2 sintering at $900^{\circ} \mathrm{C}$ or higher in other cathode materials containing $\mathrm{Sr}$ [19]. The chemical

3 incompatibility between these materials resulted in a call for an interlayer or buffer layer of

4 doped-ceria material [16,20-26] such as Sm-doped $\mathrm{CeO}_{2}$ (SDC) that is more compatible with

5 BSCF and can eliminate the interfacial reactions and reduce the interfacial resistance [27,28].

6 Unfortunately, $\mathrm{Zr}$ - Ce interdiffusion also results in interfacial reactions between YSZ and the

7 SDC buffer layer [28] and occurs while co-sintered YSZ-SDC substrates in air at $1100^{\circ} \mathrm{C}$ or

8 higher [16]. The formation of the resistive $(\mathrm{Ce}, \mathrm{Sm})_{2} \mathrm{Zr}_{2} \mathrm{O}_{7}$ phase is highly dependent on the

9 sintering temperature $[15,16,29,30]$. As a result, low sintering temperatures are often employed,

10 which do not allow for full densification of the SDC buffer layer and result in diffusion of $\mathrm{Zr}$

11 into SDC [31]. In order to prevent the YSZ-SDC reaction, advanced techniques such as pulsed

12 laser deposition and chemical solution deposition have been employed that create dense SDC

13 layers and help prevent Zr diffusion into the SDC [4,31,32]. This has led to peak power

14 densities of $\sim 2.0$ W.cm ${ }^{-2}$ for the fully dense SDC buffer layer with BSCF cathode [4]. Despite

15 the potential with these advanced techniques, techniques such as wet powder spraying and

16 screen-printing are cost effective and scalable to industry [5,9,11,13,33,34], regardless of the

17 porous SDC layer. Furthermore, the porous, rough SDC layer can be advantageous in

18 increasing the effective surface area of the triple phase boundary and enhancing the fuel cell

19 performance [6,35]. These reasons are considered partially responsible for the peak

20 performance $\left(\sim 1.9 \mathrm{~W} . \mathrm{cm}^{-2}\right)$ of a porous SDC buffer layer occurring at a sintering temperature

21 of $1350^{\circ} \mathrm{C}$ despite the detrimental $\mathrm{Zr}$ - Ce interdiffusion that occurs [36]. 
Despite comparisons between different fabrication techniques [4], effective means of comparing porous buffer layers with dense buffer layers is significantly hindered by the wide range of buffer layer thicknesses used. For example, the buffer layer thickness often ranges from $150 \mathrm{~nm}$ to $6 \mu \mathrm{m}$ with most studies being conducted with only a single thickness of the SDC buffer layer $[4,6,11,37,38]$. Recently, Constantin et. al. demonstrated the effects of varying dense buffer layer thickness [39]. In the case of the porous SDC buffer layers, there are many competing factors including pinholes in the buffer layer, interfacial reactions and improved triple phase boundary. To our knowledge, no studies have investigated the tradeoffs and interfacial reactions.

In the present study, wet powder spraying is employed to create a porous SDC buffer layer.

12 The thickness of the buffer layer is varied between $0.4 \mu \mathrm{m}$ and $2.3 \mu \mathrm{m}$ and the effect on 13 performance, resistance, and interfacial reactions is investigated. was then laminated and co-sintered [40] at $1200^{\circ} \mathrm{C}$ for 2 hrs. After sintering, an SDC buffer layer was deposited by wet powder spraying. Six different samples were prepared by spraying 20, 40, 60, 80, 100 and 120 layers of SDC onto the pre-sintered substrates. The substrates were then sintered at $1400^{\circ} \mathrm{C}$ for $4 \mathrm{hrs}$ for a final anode thickness of $\sim 250 \mu \mathrm{m}$ and electrolyte 
1 thickness of $\sim 10 \mu \mathrm{m}$. The sintered buffer layer thickness was $\sim 0.4 \mu \mathrm{m}, \sim 0.8 \mu \mathrm{m}, \sim 1.1 \mu \mathrm{m}, \sim 1.5$

$2 \mu \mathrm{m}, \sim 1.9 \mu \mathrm{m}$ and $\sim 2.3 \mu \mathrm{m}$ for the 20, 40, 60, 80, 100 and 120 layers sprayed, respectively. The

3 BSCF+SDC (70:30 w/w) cathode was then spray deposited and the cells were sintered at

$4 \quad 1000^{\circ} \mathrm{C}$ for $5 \mathrm{hrs}$ for a final cathode thickness of $\sim 4 \mu \mathrm{m}$. The prepared substrates were $15 \mathrm{~mm}$

$5 \quad$ in diameter with a cathode area of $0.7 \mathrm{~cm}^{2}$.

\section{$6 \quad 2.2$ Characterization}

7 The fuel cell performance was measured using the current voltage (IV) method. A digital

8 SourceMeter (Keithley 2420) was interfaced with a computer for measurement and recording

9 of the fuel cells open circuit voltage (OCV), polarization and power density. Electrochemical impedance spectroscopy (EIS) of the fuel cells was conducted with a Solartron 1260 A

11 frequency response analyzer with a Solartron 1287 Potentiostat under OCV conditions. EIS

12 was recorded over a frequency range of $10^{6}$ to $0.1 \mathrm{~Hz}$ with a signal amplitude of $10 \mathrm{mV}$. The

13 fuel cells cross sectional morphology was assessed with a scanning electron microscope (SEM)

14 and energy dispersive X-ray spectroscopy (EDX). The SEM and EDX analysis was performed

15 at $8 \mathrm{kV}$ and a working distance of $15 \mathrm{~mm}$. The magnification for the EDX analysis was set to

$1685,000 \mathrm{x}$ and the probe size estimated for these conditions is 1 cubic micron.

$17 \quad 2.3$ Testing setup

Testing using the IV method and EIS occurred in a tubular furnace, which was heated, to $800^{\circ} \mathrm{C}$ at $5^{\circ} \mathrm{C}$ per minute. The fuel cells were tested with hydrogen at a flow rate of $100 \mathrm{~mL}$ $20 \min ^{-1}$. The flow of hydrogen was regulated with a mass flow controller and LabView software. 21 Air was used as the oxidant and was supplied by natural convection in the furnace. The 
1 prepared fuel cell was sealed on a quartz tube with silver paste. Silver paste was applied to the

2 cathode and silver wire was used as the current collector for both the anode and cathode. The

3 fuel cell temperature was monitored with a K-type thermocouple placed on the outside of the

4 quartz tube.

\section{3. RESULTS AND DISCUSSION}

\section{$6 \quad 3.1$ Fuel cell performance}

7 Each of the fuel cells tested at $800^{\circ} \mathrm{C}$ achieved significant performance despite the reaction

8 between the YSZ and SDC layers which is known to occur at $1400^{\circ} \mathrm{C}$ [37]. However, a definite

9 trend was observed in fuel cell performance and polarization as the thickness of the SDC layer

was varied. Fig. 1 shows a comparison of the fuel cell performance for the 20, 40, 60, 80, 100

and 120 layers of SDC sprayed. Initially, the fuel cell performance improved with increased

buffer layer thickness. The peak power density for the 20, 40, 60 and 80 sprayed layers was

13 398, 478, 948 and $1106 \mathrm{~mW} \cdot \mathrm{cm}^{-2}$, respectively. With further increase of the buffer layer

thickness, the performance declined. With 100 and 120 layers of SDC sprayed the fuel cell

15 only achieved 884 and $845 \mathrm{~mW} \cdot \mathrm{cm}^{-2}$, respectively. The trend is surprising because the preparation for the cells was identical except for the variation in the number of SDC layers sprayed and the resulting buffer layer thickness. In fact, increasing the thickness of an electrolyte layer is known to cause increased ohmic resistance and reduced fuel cell performance. The exact opposite occurs for the fuel cell initially, followed by a decrease in 
1 for a buffer layer of $\sim 0.4 \mu \mathrm{m}$ (20 layers) to a buffer layer of $\sim 1.5 \mu \mathrm{m}$ (80 layers) differs by nearly a factor of three, demonstrating the importance of controlling the buffer layer thickness.

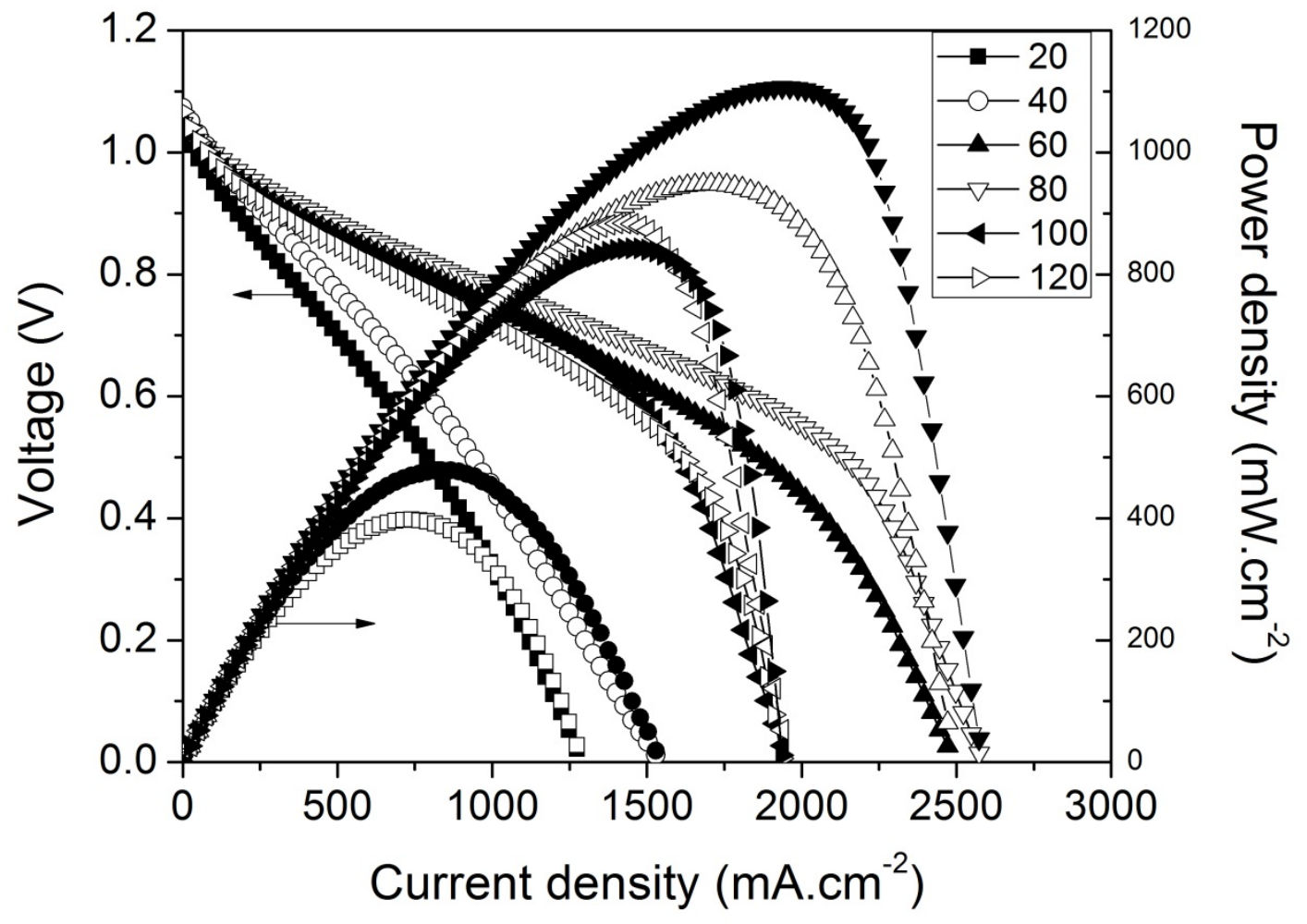

Figure 1: Fuel cell performance at $800^{\circ} \mathrm{C}$ with $20,40,60,80,100$, and 120 layers of SDC sprayed onto the substrate.

To further understand this unusual behavior, EIS was conducted on the fuel cell. Fig. 2 shows the results of the EIS with the ohmic resistance, polarization resistance and total resistance variations plotted against the number of SDC layers sprayed. As expected, the ohmic resistance of the fuel cell increases with SDC thickness as long as 40 layers of SDC or more were sprayed on the substrate. This trend is expected because increasing the SDC thickness results in a longer path for ionic conduction of oxygen ions. However, the ohmic resistance of 
1 the fuel cell with 20 layers of SDC sprayed is much higher than the ohmic resistance of any

2 other fuel cell except the 120 layers of SDC. The ohmic resistance was $0.361,0.335,0.349$,

$30.355,0.356$, and $0.364 \Omega . \mathrm{cm}^{2}$ for the $20,40,60,80,100$ and 120 layers of SDC, respectively.

4 Despite the variations in ohmic resistance, the total resistance was effected only slightly

5 because the variations in ohmic resistance are small compared to the total resistance. The total

6 resistance follows the polarization resistance much more closely, beginning at $1.28 \Omega . \mathrm{cm}^{2}$ for

720 layers of SDC sprayed and decreasing steadily with increasing layers of SDC sprayed to

$8 \quad 0.819 \Omega . \mathrm{cm}^{2}$ at 80 layers. A decrease in polarization losses appears to result from an improved

9 triple phase boundary. The SDC buffer layer does not densify fully after sintering at $1400^{\circ} \mathrm{C}$ as

10 shown in Fig. 3, resulting in an average pore size of $0.16 \mu \mathrm{m}$. This pore size is comparable to

11 the thickness of the 20 and 40 layers sprayed, which resulted in an SDC buffer layer thickness

12 of $\sim 0.4$ and $\sim 0.8 \mu \mathrm{m}$, respectively. Due to the porosity of the SDC buffer layer, which is

13 pre-sintered at $1400^{\circ} \mathrm{C}$ before applying the SDC + BSCF cathode, the triple phase boundary

14 can improve with the SDC + BSCF cathode infiltrating into the SDC buffer layer. This

15 infiltration is primarily a result of applying the SDC + BSCF cathode with the wet powder

16 spraying technique, which results in a wet application of the cathode that can flow into the

17 pores prior to drying fully. For the 20 and 40 layers, the cathode can potentially flow through

18 most of the buffer layer because the buffer layer is thin relative to the average pore size. This

19 enhanced triple phase boundary can result in decreased polarization losses, which are observed

20 between 20 and 80 layers of SDC and should affect the 100 and 120 layers of SDC as well.

21 However, with an average pore size of $0.16 \mu \mathrm{m}$ the cathode is not expected to infiltrate through 
1 the entire buffer layer when the thickness increases to $1.9 \mu \mathrm{m}$ and $~ 2.3 \mu \mathrm{m}$ for the 100 and

2120 layers of SDC, respectively. As a result, the triple phase boundary can only be enhanced to

3 a certain extent. The trend of decreasing polarization losses reverses as the polarization losses

4 began to increase for the 100 layers of SDC up to $1.37 \Omega . \mathrm{cm}^{2}$ for the 120 layers of SDC. The

5 cause of the peak performance at 80 layers of SDC is clearly related to both ohmic and

6 polarization losses and is dependent upon the cathode-buffer layer and buffer layer-electrolyte

7 interfaces of the fuel cell. Variations in the anode-electrolyte interface did not contribute

8 because the preparation was identical for these layers.

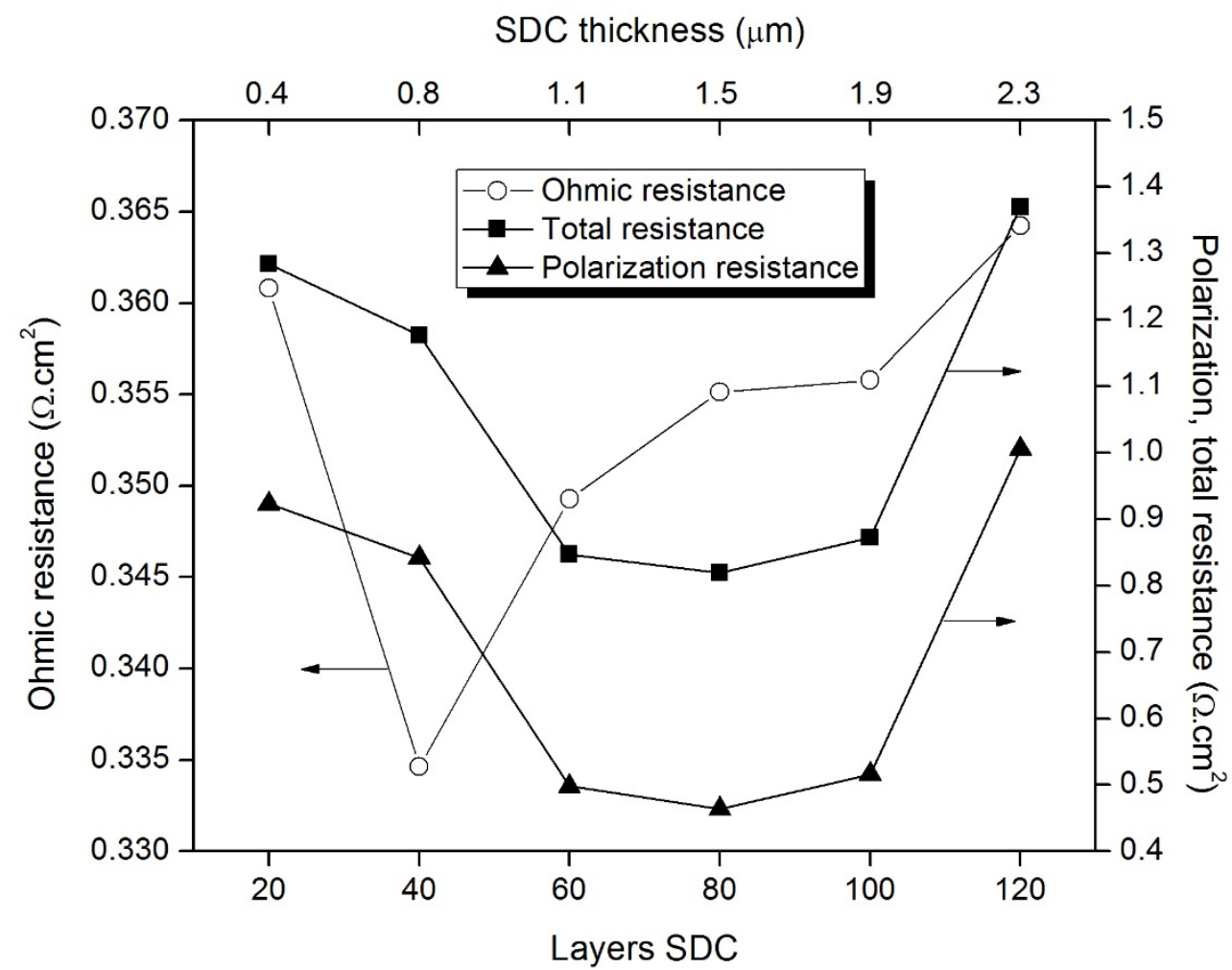

9

Figure 2: Ohmic resistance, polarization resistance and total resistance as the number of sprayed SDC layers is varied from 20 to 120 layers. 


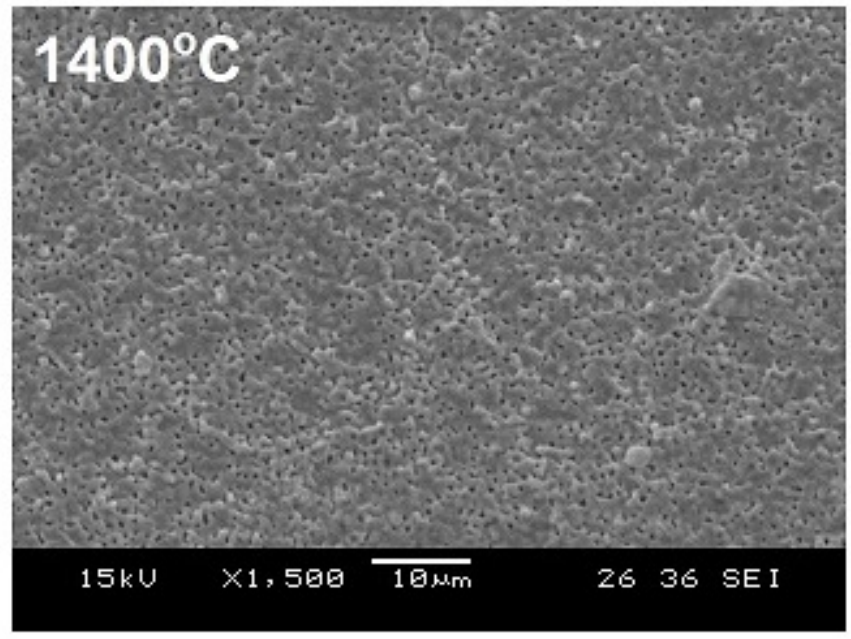

Figure 3: SEM morphologies of the SDC buffer layer surface sintered at $1400^{\circ} \mathrm{C}$.

\subsection{SEM and EDX analysis}

To gain a more comprehensive understanding of the performance variation with SDC thickness, the microstructure of the fuel cells was assessed with SEM. Fig. 4 is a comparison of the fuel cell cross sectional morphologies as the SDC buffer layer thickness is varied. With only 20 layers sprayed of SDC, the buffer layer is extremely thin between the cathode and electrolyte and is porous as shown in Fig. 3. The thin, porous buffer layer at 20 layers is likely to result in a reaction between BSCF and YSZ. EDX analysis of the YSZ-SDC interface is shown in Fig. 5. Indeed, both $\mathrm{Ba}$ and $\mathrm{Sr}$ were detected at the YSZ-SDC interface. The detrimental formation of $\mathrm{BaZrO}_{3}$ and $\mathrm{SrZrO}_{3}$ is not prevented with only 20 layers of SDC and the buffer layer was ineffective due to pin holes. The presence of $\mathrm{Ba}$ and $\mathrm{Sr}$ at the YSZ-SDC interface explains the initially high ohmic resistance of the fuel cell with 20 layers of SDC sprayed. As described in the introduction, the formation of $\mathrm{BaZrO}_{3}$ and $\mathrm{SrZrO}_{3}$ is known to create high interfacial resistance and poor performance. Fig. 6 is the EDX analysis of the YSZ-SDC interface of the fuel cell with 40 layers of SDC sprayed. Also shown is the EDX 
1 analysis within the SDC buffer layer. As shown, no Ba or Sr were detected in the fuel cell at

2 the interface. The buffer layer was thick enough to prevent direct contact between the

3 electrolyte and the cathode. The ohmic resistance of the fuel cell reduced to its minimum at 40

4 layers of SDC and then steadily increases with thickness of the SDC layer, as expected.

5 Unfortunately, the porous buffer layer with 40 layers sprayed is not effective at preventing $\mathrm{Zr}$

6 diffusion into the SDC layer. Fig. 6 indicates that significant $\mathrm{Zr}$ is detected within the SDC

7 buffer layer were $\mathrm{Ba}$ and $\mathrm{Sr}$ are also present. Reactions can still occur to form $\mathrm{BaZrO}_{3}$ and

$8 \mathrm{SrZrO}_{3}$ within the buffer layer, but the reactions were prevented at the YSZ interface directly,

9 which reduced the ohmic resistance of the fuel cell for this condition. 
a)

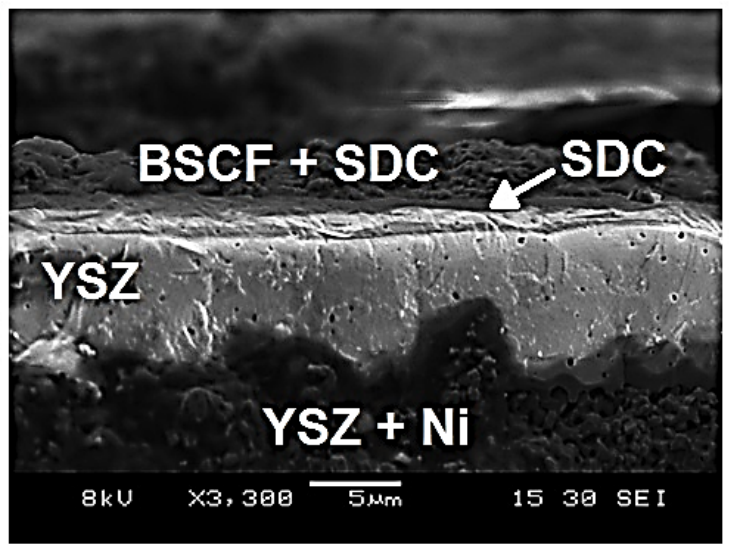

c)

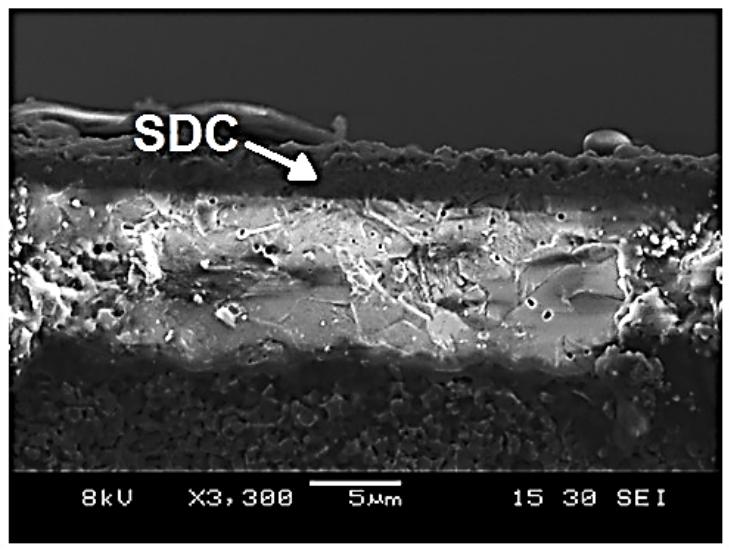

e)

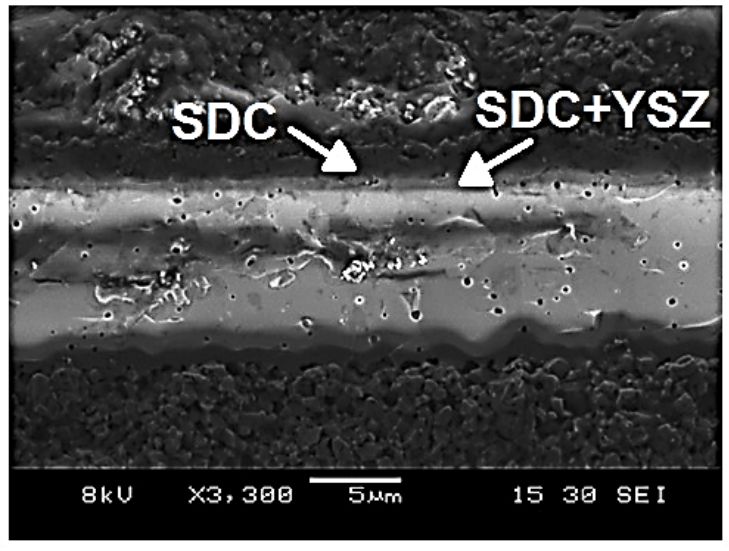

b)

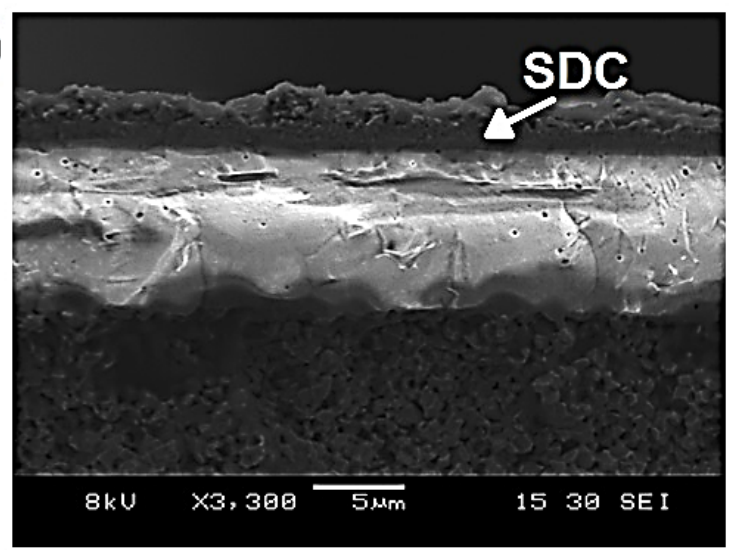

d)

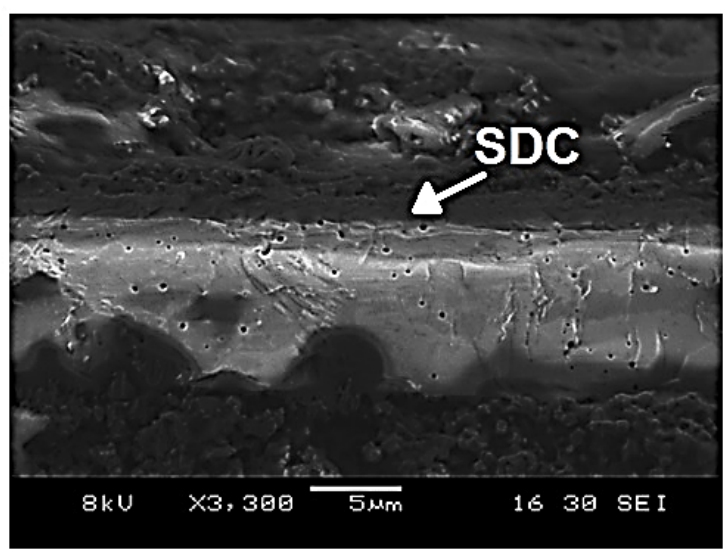

f)

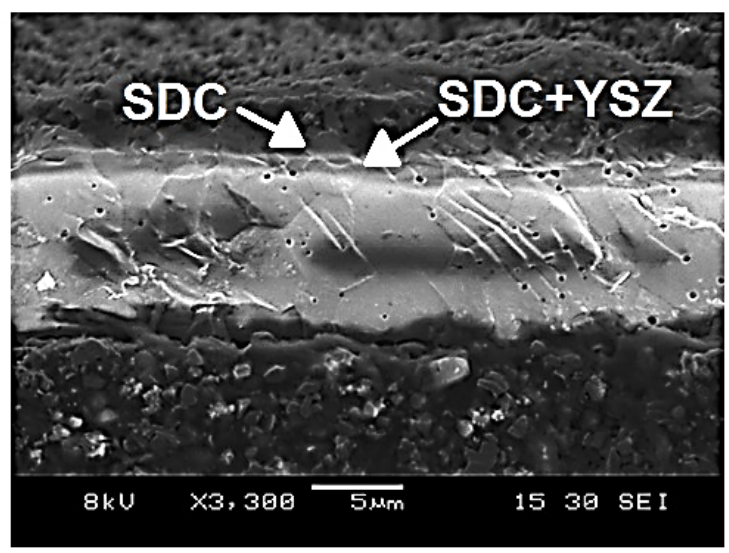




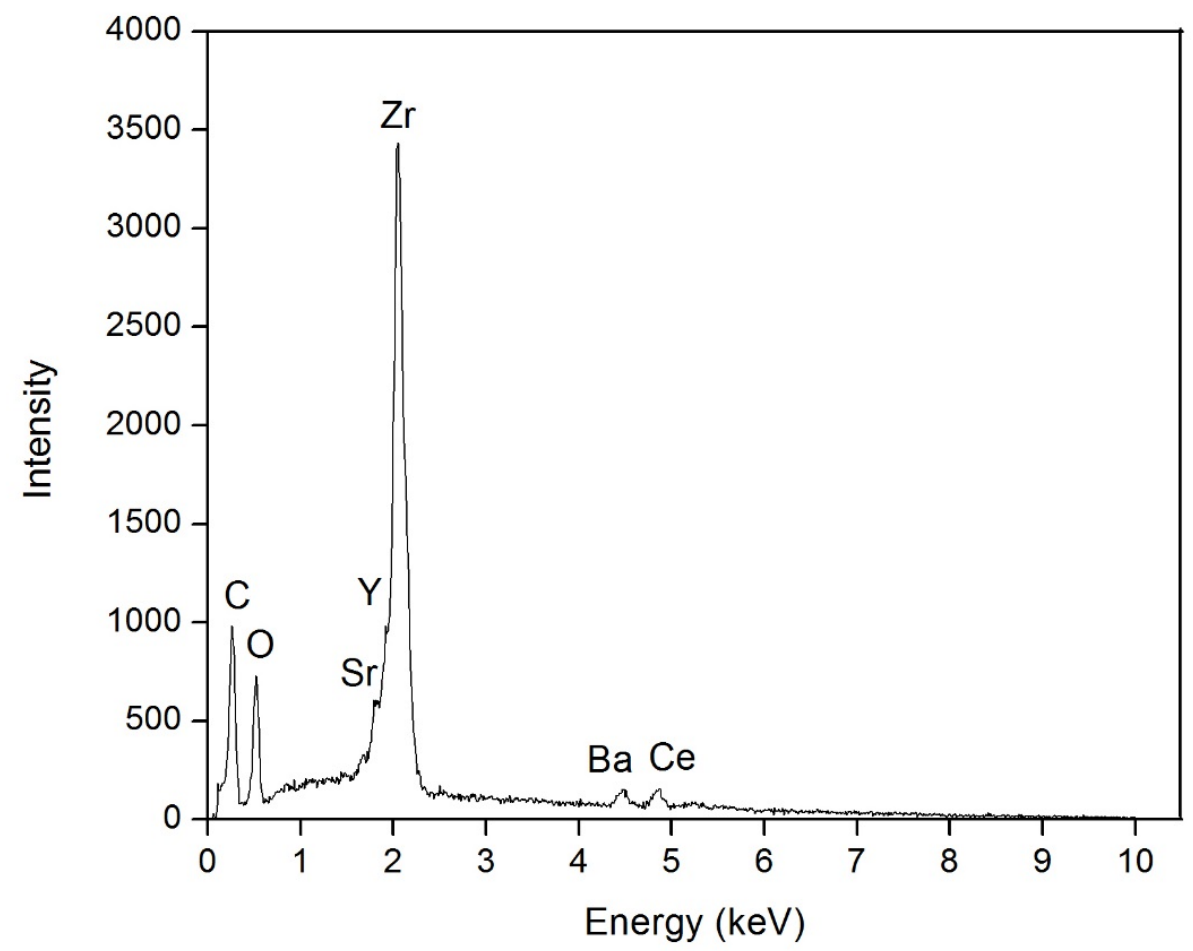

1

Figure 5: EDX analysis at the YSZ-SDC interface with 20 layers of SDC sprayed. 


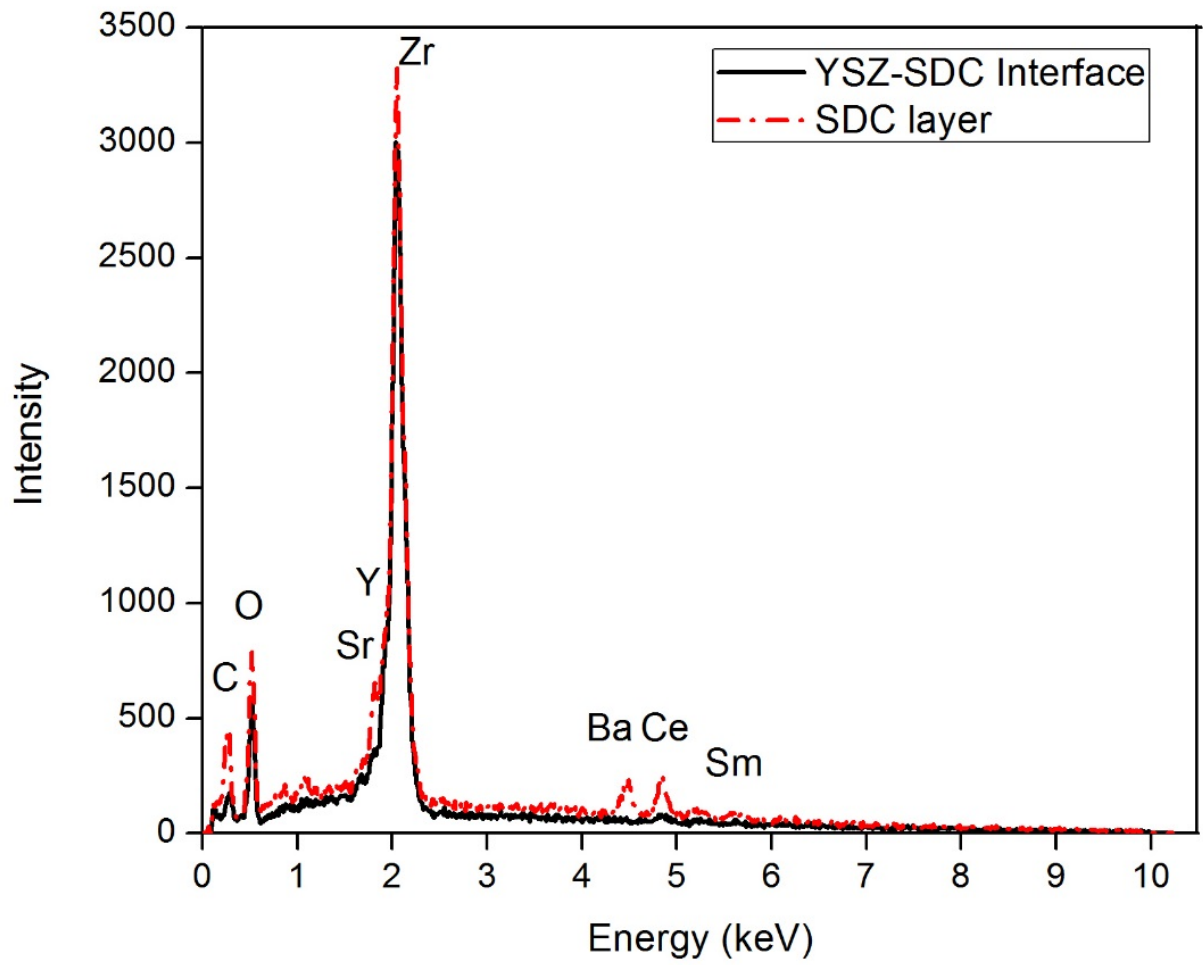

1

Figure 6: EDX analysis of the YSZ-SDC interface and within the SDC layer with 40 layers of SDC sprayed.

4 Fig. 4 shows the growth of the SDC layer with the number of layers of SDC sprayed. However,

$5 \quad$ Fig. 4e and 4f show an increasingly defined layer between the YSZ and SDC buffer layer. This

6 layer appears as an intermediate gray color in comparison to the lighter YSZ layer below and the

7 darker SDC layer above. This layer, although present in the earlier samples, is becoming thicker.

8 Fig. 7 is the EDX analysis of the interface between this grey area and the darker SDC layer 9 above for 80 layers of SDC sprayed. As shown, no Ba or Sr were detected at this interface.

10 However, Zr, Y, Ce, Sm and O were detected. This grey area is a layer of interfacial reaction

11 between the YSZ-SDC layers. As discussed in the introduction, YSZ and SDC can also react at 
1 high sintering temperatures to form the resistive (Ce,Sm) ${ }_{2} \mathrm{Zr}_{2} \mathrm{O}_{7}$ phase. This resistive phase is

2 growing as shown by the SEM. As this layer grows, the increasing interfacial resistance

3 contributes to the polarization and ohmic resistance of the fuel cell. Fig. 8 shows a similar

4 analysis of the 120 layers of SDC. For this cell, no Ba or Sr were initially detected at the

5 YSZ-SDC reaction interface. However, the resistive $(\mathrm{Ce}, \mathrm{Sm})_{2} \mathrm{Zr}_{2} \mathrm{O}_{7}$ phase cannot be prevented

6 with $\mathrm{Zr}$, Ce, Sm and $\mathrm{O}$ all present. Fortunately, this resistive phase is not as detrimental to the

7 fuel cells performance as $\mathrm{BaZrO}_{3}$ and $\mathrm{SrZrO}_{3}$ [39], which causes the performance to initially

8 improve with thickness until the (Ce,Sm) ${ }_{2} \mathrm{Zr}_{2} \mathrm{O}_{7}$ phase becomes too thick and the performance

9 degrades. The increasing region of YSZ-SDC interfacial reactions appears to alter the

10 morphology and influence the activation and mass transport losses of the fuel cell by decreasing

$11 \mathrm{O}_{2}$ and $\mathrm{O}^{2-}$ transfer to the YSZ layer. This results in an increase in polarization losses and a 12 decrease in performance with a thicker SDC buffer layer. 


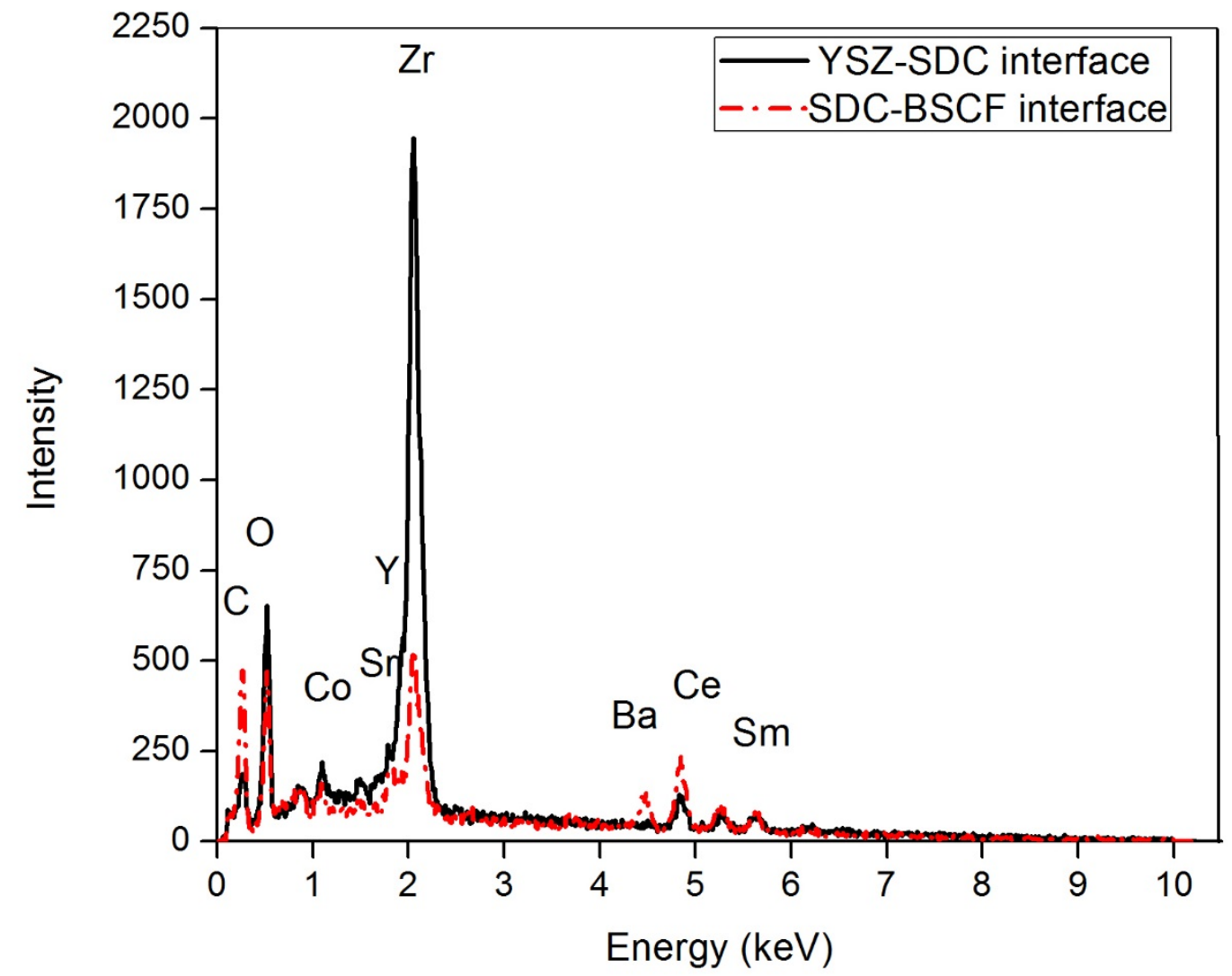

1

2 Figure 7: EDX analysis of the YSZ-SDC reaction interface and SDC-BSCF interface with 80

layers of SDC sprayed. 


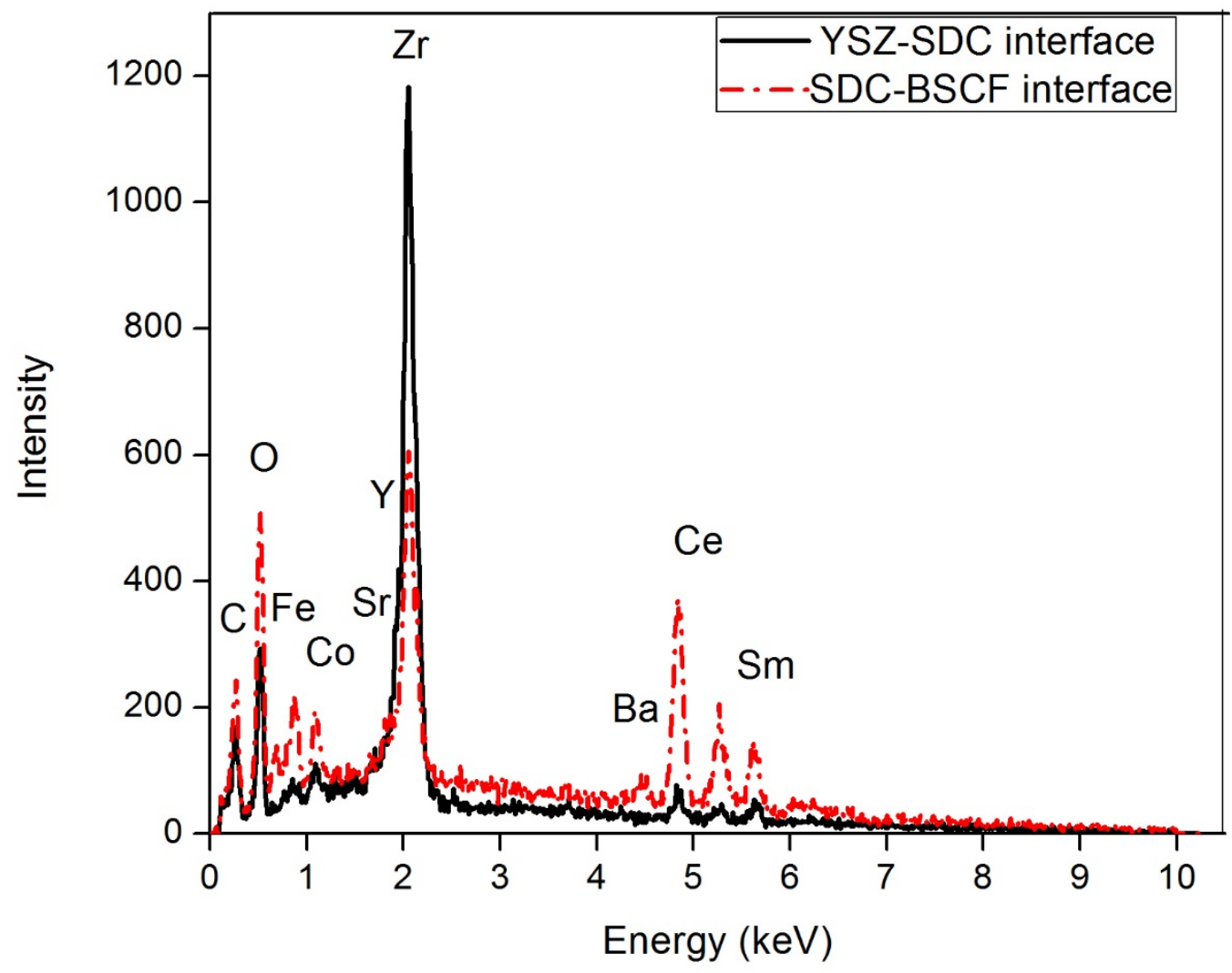

1

2 Figure 8: EDX analysis of the YSZ-SDC reaction interface and SDC-BSCF interface with 120 layers of SDC sprayed.

The EDX analysis shown in Fig. 7 and Fig. 8 also show that $\mathrm{Zr}$ is present at the SDC-BSCF

5 interface. There is not as much $\mathrm{Zr}$ present at this interface as the YSZ-SDC reaction interface,

6 but the formation of both $\mathrm{BaZrO}_{3}$ and $\mathrm{SrZrO}_{3}$ is still possible in the region near the SDC-BSCF

7 interface. The overall effect of these interfacial reactions is an increase in the ohmic and

8 polarization resistance, which contribute to a gradual decline in fuel cell performance. These

9 reactions cause the decrease in fuel cell performance as the SDC buffer layer becomes thicker.

\section{CONCLUSION}


1 The thickness of the SDC buffer layer has a significant effect on the overall fuel cell

2 performance. An optimal porous SDC buffer layer thickness of $\sim 1.5 \mu \mathrm{m}$ (80 layers of SDC

3 sprayed) was uncovered with a peak power density of $1106 \mathrm{~mW} \cdot \mathrm{cm}^{-2}$ at $800^{\circ} \mathrm{C}$. The peak

$4 \quad$ power density was nearly 3 times higher than the peak power density of the 20 layers sprayed.

$5 \quad$ For layers thinner than $1.5 \mu \mathrm{m}$, the reaction between BSCF and YSZ as well as the decreased

6 triple phase boundary contribute to reduced performance. For layers thicker than $1.5 \mu \mathrm{m}$, the

7 increased ohmic resistance due to the buffer layer thickness and the reactions between YSZ

8 and SDC and between BSCF and YSZ contribute to decreased performance. An optimal buffer

$9 \quad$ layer thickness results, which balances these contributions.

10 ACKNOWLEDGEMENT

11 This work was supported by the National Science Foundation under grant CBET-1403405 and

12 an award from Empire State Development's Division of Science, Technology and Innovation

13 (NYSTAR) through the Syracuse Center of Excellence, under award number \#C120183.

14 REFERENCES

15 [1] B.C.H. Steele, A. Heinzel, Materials for fuel-cell technologies, Nat. 414 (2001) 345-352.

16 [2] R.J. Gorte, Recent developments towards commercialization of solid oxide fuel cells, AIChE J. 51 (2005) 2377-2381.

18 [3] S. de Souza, S.J. Visco, L.C. De Jonghe, Reduced-temperature solid oxide fuel cell based on YSZ thin-film electrolyte, J. Electrochemical Society 144 (1997) L35-L37. 
1 [4] D. Chen, G. Yang, Z. Shao, F. Ciucci, Nanoscaled Sm-doped $\mathrm{CeO}_{2}$ buffer layers for intermediate-temperature solid oxide fuel cells, Electrochemistry Commun. 35 (2014) 131134.

4 [5] Z. Shao, W. Zhou, Z. Zhu, Advanced synthesis of materials for intermediate-temperature solid oxide fuel cells, Prog. in Mater. Sci. 57 (2012) 804-874.

[6] C. Li, H. Shi, R. Ran, C. Su, Z. Shao, Thermal inkjet printing of thin-film electrolytes and buffering layers for solid oxide fuel cells with improved performance, Int. J. Hydrogen Energy 38 (2013) 9310-9319.

[7] J-H. Song, S-I. Park, J-H. Lee, H-S. Kim, Fabrication characteristics of an anode-supported thin-film electrolyte fabricated by the tape casting method for IT-SOFC, J. Mater. Process. Technol. 198 (2008) 414-418.

[8] J. Will, A. Mitterdorfer, C. Kleinlogel, D. Perednis, L.J. Gauckler, Fabrication of thin electrolytes for second-generation solid oxide fuel cells, Solid State Ionics 131 (2000) 79_ 96.

[9] H. Shi, W. Zhou, R. Ran, Z. Shao, Comparative study of doped ceria thin-film electrolytes prepared by wet powder spraying with powder synthesized via two techniques, J. Power Sources 195 (2010) 393-401.

[10] F. Zhao, A.V. Virkar, Dependence of polarization in anode-supported solid oxide fuel cells on various cell parameters, J. Power Sources 141 (2005) 79-95. 
1 [11] H. Shi, R. Ran, Z. Shao, Wet powder spraying fabrication and performance optimization of IT-SOFCs with thin-film ScSZ electrolyte, Int. J. Hydrogen Energy 37 (2012) 11251132.

[12] Z. Shao, S.M. Haile, J. Ahn, P.D. Ronney, Z. Zhan, S.A. Barnett, A thermally

self-sustained micro solid-oxide fuel-cell stack with high power density, Nat. 435 (2005) 795-798.

[13] S.P. Simner, J.F. Bonnett, N.L. Canfield, K.D. Meinhardt, J.P. Shelton, V.L. Sprenkle, J.W. Stevenson, Development of lanthanum ferrite SOFC cathodes, J. Power Sources 113 (2003) 1-10.

[14] K. Wang, R. Ran, W. Zhou, H. Gu, Z. Shao, J. Ahn, Properties and performance of $\mathrm{Ba}_{0.5} \mathrm{Sr}_{0.5} \mathrm{Co}_{0.8} \mathrm{Fe}_{0.2} \mathrm{O}_{3-\delta}+\mathrm{Sm}_{0.2} \mathrm{Ce}_{0.8} \mathrm{O}_{1.9}$ composite cathode, J. Power Sources 179 (2008) 60-68.

[15] Z. Duan, M. Yang, A. Yan, Z. Hou, Y. Dong, Y. Chong, M. Cheng, W. Yang, $\mathrm{Ba}_{0.5} \mathrm{Sr}_{0.5} \mathrm{Co}_{0.8} \mathrm{Fe}_{0.2} \mathrm{O}_{3-\delta}$ as a cathode for IT-SOFCs with a GDC interlayer, J. Power Sources 160 (2006) 57-64.

[16] A. Martínez-Amesti, A. Larrañaga, L.M. Rodríguez-Martínez, M.L. Nó, J.L. Pizarro, A. Laresgoiti, M.I. Arriortua, Chemical compatibility between YSZ and SDC sintered at different atmospheres for SOFC applications, J. Power Sources 192 (2009) 151-157.

[17] Z. Jiang, C. Xia, F. Chen, Nano-structured composite cathodes for intermediate-temperature solid oxide fuel cells via an infiltration/impregnation technique, Electrochimica Acta 55 (2010) 3595-3605. 
[18] A. Petric, P. Huang, F. Tietz, Evaluation of La-Sr-Co-Fe-O perovskites for solid oxide fuel cells and gas separation membranes, Solid State Ionics 135 (2000) 719-725.

[19] S. Simner, M. Anderson, J. Bonnett, J. Stevenson, Enhanced low temperature sintering of (Sr, Cu)-doped lanthanum ferrite SOFC cathodes, Solid State Ionics 175 (2004) 79-81.

[20] J. Szász, F. Wankmüller, V. Wilde, H. Störmer, D. Gerthsen, N.H. Menzler, E. Ivers-Tiffée, High-performance cathode/ electrolyte interfaces for SOFC, ECS Trans., 68 (1) (2015) 763-771.

[21] A. Mai, V. A.C. Haanappel, F. Tietz, D. Stöver, Ferrite-based perovskites as cathode materials for anode-supported solid oxide fuel cells: Part II. Influence of the CGO interlayer, Solid State Ionics 177 (2006) 2103-2107.

[22] S. Uhlenbruck, T. Moskalewicz, N. Jordan, H.-J. Penkalla, H.P. Buchkremer, Element interdiffusion at electrolyte-cathode interfaces in ceramic high-temperature fuel cells, Solid State Ionics 180 (2009) 418-423.

[23] N. Jordan, W. Assenmacher, S. Uhlenbruck, V.A.C. Haanappel, H.P. Buchkremer, D. Stöver, W. Mader, $\mathrm{Ce}_{0.8} \mathrm{Gd}_{0.2} \mathrm{O}_{2-\delta}$ protecting layers manufactured by physical vapor deposition for IT-SOFC, Solid State Ionics 179 (2008) 919-923.

[24] B. Moreno, R. Fernández-González, J.R. Jurado, A. Makradi, P. Nuñez, E. Chinarro, Fabrication and characterization of ceria-based buffer layers for solid oxide fuel cells, Int. J. Hydrogen Energy 39 (2014) 5433-5439.

[25] T.L. Nguyen, K. Kobayashi, T. Honda, Y. Iimura, K. Kato, A. Neghisi, K. Nozaki, F. Tappero, K. Sasaki, H. Shirahama, K. Ota, M. Dokiya, T. Kato, Preparation and evaluation 
of doped ceria interlayer on supported stabilized zirconia electrolyte SOFCs by wet ceramic processes, Solid State Ionics 174 (2004) 163-174.

[26] D. Mesguich, C. Aymonier, J.M. Bassat, F. Mauvy, E. You, J.J. Watkins, Low temperature deposition of undoped ceria thin films in scCO2 as improved interlayers for IT-SOFC, Chem. Mater. 23 (2011) 5323-5330.

[27] S. Charojrochkul, K.-L. Choy, B.C.H. Steele, Cathode/electrolyte systems for solid oxide fuel cells fabricated using flame assisted vapour deposition technique, Solid State Ionics 121 (1999) 107-113.

[28] A. Tsoga, A. Gupta, A. Naoumidis, P. Nikolopoulos, Gadolinia-doped ceria and yttria stabilized zirconia interfaces: regarding their application for SOFC technology, Acta mater. 48 (2000) 4709-4714.

[29] A. Martínez-Amesti, A. Larrañaga, L.M. Rodríguez-Martínez, M.L. Nó, J.L. Pizarro, A. Laresgoiti, M.I. Arriortua, Influence of SDC-YSZ contact at different atmospheres in SOFC operation and processing conditions, J. Electrochem. Soc. 156 (2009) B856-B861.

[30] A. Martínez-Amesti, A. Larrañaga, L.M. Rodríguez-Martínez, A.T. Aguayo, J.L. Pizarro, M.L. Nó, A. Laresgoiti, M.I. Arriortua, Reactivity between $\mathrm{La}(\mathrm{Sr}) \mathrm{FeO}_{3}$ cathode, doped $\mathrm{CeO}_{2}$ interlayer and yttria-stabilized zirconia electrolyte for solid oxide fuel cell applications, J. Power Sources 185 (2008) 401-410.

[31] Z. Lu, X. Zhou, D. Fisher, J. Templeton, J. Stevenson, N. Wu, A. Ignatiev, Enhanced performance of an anode-supported YSZ thin electrolyte fuel cell with a laser-deposited $\mathrm{Sm}_{0.2} \mathrm{Ce}_{0.8} \mathrm{O}_{1.9}$ interlayer, Electrochemistry Commun. 12 (2010) 179-182. 
[32] E-O. Oh, C.M. Whang, Y.R. Lee, S.Y. Park, D.H. Prasad, K.J. Yoon, J.W. Son, J.H. Lee, H.W. Lee, Extremely thin bilayer electrolyte for solid oxide fuel cells (SOFCs) fabricated by chemical solution deposition (CSD), Adv. Mater. 24 (2014) 3373-3377.

[33] W. Zhou, H. Shi, R. Ran, R. Cai, Z. Shao, W. Jin, Fabrication of an anode-supported yttria-stabilized zirconia thin film for solid-oxide fuel cells via wet powder spraying, J. Power Sources 184 (2008) 229-237.

[34] A. Ruder, H. P. Buchkremer, H. Jansen, W. Malléner, D. Stöver, Wet powder spraying - a process for the production of coatings, Surf. and Coatings Technol. 53 (1992) 71-74.

[35] T. Suzuki, P. Jasinski, V. Petrovsky, H.U. Anderson, F. Dogan, Performance of a porous electrolyte in single-chamber SOFCs, J. Electrochem. Soc. 152 (3) (2005) A527-A531.

[36] R.J. Milcarek, K. Wang, M.J. Garrett, J. Ahn, Performance investigation of dual layer yttria-stabilized zirconia - samaria-doped ceria electrolyte for intermediate temperature solid oxide fuel cells, J. Electrochem. En. Conv. Stor. 13 (1) (2016) doi: 10.1115/1.4032708.

[37] Z. Wang, X. Huang, Z. Lv, Y. Zhang, B. Wei, X. Zhu, Z. Wang, Z. Liu, Preparation and performance of solid oxide fuel cells with YSZ/SDC bilayer electrolyte, Ceramics Int. 41 (2015) 4410-4415.

[38] W-X. Kao, M-C. Lee, T-N Lin, C-H. Wang, Y-C. Chang, Fabrication and characterization of a $\mathrm{Ba}_{0.5} \mathrm{Sr}_{0.5} \mathrm{Co}_{0.8} \mathrm{Fe}_{0.2} \mathrm{O}_{3-\delta}$ - gadolinia-doped ceria cathode for an anode-supported solid-oxide fuel cell, J. Power Sources 195 (2010) 2220-2223. 
1 [39] G. Constantin, C. Rossignol, P. Briois, A. Billard, L. Dessemond, E. Djurado, Efficiency of a dense thin CGO buffer layer for solid oxide fuel cell operating at intermediate temperature, Solid State Ionics 249-250 (2013) 98-104.

4 [40] H. Ohrui, T. Matushima, T. Hirai, Performance of a solid oxide fuel cell fabricated by co-firing, J. Power Sources 71 (1998) 185-189. 


\section{FIGURE CAPTIONS}

Figure 1: Fuel cell performance at $800^{\circ} \mathrm{C}$ with $20,40,60,80,100$, and 120 layers of SDC sprayed onto the substrate. (1 column image)

Figure 2: Ohmic resistance, polarization resistance and total resistance as the number of sprayed SDC layers is varied from 20 to 120 layers. (1 column image)

Figure 3: SEM morphologies of the SDC buffer layer surface sintered at $1400^{\circ} \mathrm{C}$. (1 column image)

Figure 4: Cross sectional morphologies of the fuel cell at a) 20 b) 40 c) 60 d) 80 e) 100 and f) 120 layers of SDC sprayed. (1.5 or 2 column image)

Figure 5: EDX analysis at the YSZ-SDC interface with 20 layers of SDC sprayed. (1 column image)

Figure 6: EDX analysis of the YSZ-SDC interface and within the SDC layer with 40 layers of SDC sprayed. (1 column image)

Figure 7: EDX analysis of the YSZ-SDC reaction interface and SDC-BSCF interface with 80 layers of SDC sprayed. (1 column image)

Figure 8: EDX analysis of the YSZ-SDC reaction interface and SDC-BSCF interface with 120 layers of SDC sprayed. (1 column image) 